\title{
Huub van Baar and Angéla Kóczé, eds. 2020. The Roma and Their Struggle for Identity in Contemporary Europe, Berghan Books.
}

\section{Book review by}

\section{Deniz Selmani}

selmanideniz@gmail.com

Program Manager, Institute for Research and Policy Analysis - Romalitico

ORCID: https://orcid.org/0000-0002-7095-215X

Deniz Selmani is a co-founder of the Institute for Research and Policy Analysis - Romalitico and the civic movement AVAJA. His professional experience includes work for civil society organizations and think tanks. He was selected to participate in the Obama Foundation's Europe Leaders program, which identifies emerging leaders working in government, civil society, and the private sector who have demonstrated a commitment to advancing the common good. His main interests are political parties, electoral systems, human rights, and strategic communication.

\section{Critical}

Romani Studies 
The book The Roma and Their Struggle for Identity in Contemporary Europe, edited by Huub van Baar and Angéla Kóczé, consists of five major parts. The first part introduces the reader to the struggle for Romani identity in contemporary Europe. The second part covers the topics of society, history, and citizenship. The third part discusses the challenge of "ethnic minority governance" in Europe. The fourth part is dedicated to the topics of gender and social movements. The final part of the book explores the topics of art and culture.

Van Baar begins by examining the epistemology of art, as a significant element in the formation of Romani identity. In chapter 2, Julia Szalai discusses segregation as a form of oppression and demonstrates the reasons behind such practices by many state apparatuses. In chapter 3, Nidhi Trehan analyzes how different stakeholders during the socialist and post-socialist era in Hungary were approaching the socalled "Gypsy question" by looking into various ethnographic materials. In chapter 4, Angéla Kóczé discusses how a restructured welfare system in the post-1989 era, together with the intersection of race, gender, and class in Central and Eastern Europe, largely contributed to long-term poverty among Romani communities, especially among Romani women. In chapter 5, Huub van Baar argues that, to a large degree, the Europeanization of the representation of Roma cannot be seen as Europeanization of the Roma issue, identity, or policy, and explains how the European citizenship of Roma has deteriorated. In chapter 6, Iulius Rostas looks closely at the EU's adoption and implementation of policies and programs designed to improve the lives of Roma but inadvertently have worsened them, mainly because many stakeholders were approaching and defining "the Roma" differently and problematizing the situation of Roma. In chapter 7, Debra Schultz provides evidence of activism by Romani women to influence the agenda of various actors and shows how the personal and collective activities of these women affects Romani identity formation. In chapter 8, Violetta Zentai studies movements by Romani movements in Central and Eastern Europe, describing how Romani women, in particular, swapped intersectional reasoning with what she calls "transformative anti-essentialism." In chapter 9, Carol Silverman discusses the relationship between culture and ethnicity, arguing that culture and tradition, as concepts, are not fixed but rather are instruments used to portray a particular identity. In chapter 10, Tina Magazzini explores how Romani art and culture influence identity formation, through an interview with the two co-directors of the European Roma Institute for Arts and Culture (ERIAC), Tímea Junghaus and Anna Mirga-Kruszelnicka. In chapter 11, Annabel Tremlett and Delaine Le Bas discuss the challenges and possibilities that contemporary Romani art movements offer in identity formation, through interviews with the artists Damian Le Bas and Delaine Le Bas.

The book is a bold new look at the forming of Romani identity in contemporary Europe, based on wideranging, insightful analyses of societal events that shaped the process of performing Romani identity. The authors make a fresh and relevant contribution to Romani studies, in which they clearly challenge the knowledge production of Roma identity in the twenty-first century. The topics covered by the authors range from postcolonial theory to critical race theory, to feminism, political theory, and anthropology, in which hegemony seems to play a crucial role. The authors challenge the European perception of the construction of Romani identity, critically analyzing and deconstructing this perception, while offering readers a means to better understand the complexity, essentialism, and hybridity of the formation of Roma identity. The book digs deep to understand and to explain to readers the struggle of Roma in the process of forming their identity in contemporary Europe. 
The authors demonstrate that Romani identities are formed through attempts to control. Szalai writes, "segregation not only implies direct control over minority, but also helps the practicing of power over large segments of society." However, Romani movements around Europe are still struggling to take control of the formation of Romani identity, mainly because of "state propaganda," as Trehan demonstrates. One method of state propaganda is to create false narratives to exclude Roma from society. Many populist leaders are using such narratives, such as Viktor Orbán, who imposes the label "Gypsy crime” on Romani communities in Hungary and attaches it to Romani identity. The other method, as Rostas discusses, is the exclusion of Roma from policy design, which contributes to the paradox of bringing in many policies while the situation of Roma worsens. Having said this, the dominant narrative created by the majority is that Roma do not want to integrate into society, despite all the efforts of the EU and national governments, which is a very dangerous narrative attached to Roma identity.

In my view, the volume has only one limitation, which is to not look critically at religion as a cultural system that contributes to the formation of Romani identity, especially after the fall of communism and regarding post-communist policies on practicing religion. This would give readers deeper insight into the strong influence of religious authorities over the construction of Roma identity. However, the authors raise a lot of important questions that should be studied. One particular area for further review should be community mobilization in the Romani movement, as populism and far-right movements are growing in Europe.

I would strongly recommend this book to academics, activists, and students of political science, social philosophy, and sociology, and anyone who would like to have a critical perspective on the struggle of Roma for identity. The book presents a wide array of social issues related to Roma across Europe. In conclusion, this book is a major contribution to Romani studies because of the insightful perceptions it provides as the authors discuss various ideas and phenomena related to the struggle of identity formation. 